\title{
ФУНКЦІЇ ПЕДАГОГІЧНИХ ДИСЦИПЛІН У СИСТЕМІ ФУНДАМЕНТАЛЬНОЇ ПРОФЕСІЙНОЇ ПІДГОТОВКИ МАЙБУТНЬОГО ВЧИТЕЛЯ ПОЧАТКОВОї ШКОЛИ
}

Садова В. В. Функції педагогічних дисциплін у системі фундаментальної професійної підготовки майбутнього вчителя початкової школи.

У статті на основі висвітлення специфіки професійної підготовки майбутніх учителів початкової школи визначаються та аналізуються традиційні й новітні функції педагогічних дисциплін. Автор конкретизує терміни «професійно-педагогічна підготовка» та «професійнопедагогічна підготовка майбутнього вчителя початкової школи».

Ключові слова: майбутній учитель початкової школи, професійно-педагогічна підготовка, професійно-педагогічна підготовка майбутнього вчителя початкової школи, традиційні та інноваційні функції, педагогічні дисципліни.

Садовая В. В. Функции педагогических дисциплин в системе фундаментальной профессиональной подготовки будущего учителя начальной школы.

В статье на основе освещения специфики профессиональной подготовки будущих учителей начальной школы определяются и анализируются традиционные и новейшие функции педагогических дисциплин. Автор конкретизирует термины «профессиональнопедагогическая подготовка» и «профессионально-педагогическая подготовка будущего учителя начальной школы».

Ключевые слова: будущий учитель начальной школы, профессиональнопедагогическая подготовка, профессионально-педагогическая подготовка будущего учителя начальной школы, традиционные и инновационные функции, педагогические дисциплины.

Sadova V. V. Pedagogical disciplines functions in the system of basic fundamental training of future primary school teachers.

Traditional and innovative functions of pedagogical disciplines are defined and analyzed on the basis of spotlight coverage of specific features concerning professional training of primary school future teachers. The author specifies the terms «professional and pedagogical training» and «professional and pedagogical training of a primary school future teacher».

Key words: a future primary school teacher, professional and pedagogical training, professional and pedagogical training of a future primary school teacher, traditional and innovative functions, pedagogical disciplines.

У сучасного студента вищого педагогічного навчального закладу, поза залежністю від напряму майбутньої професійної діяльності, педагогічна підготовка повинна бути фундаментальною. Саме на основі засвоєння змісту педагогічних дисциплін формується професійно-світоглядна позиція майбутнього педагога, активується пізнавальний потенціал, розвиваються індивідуально-творчі здібності, методичні та дослідницькі вміння, інші професійно важливі якості, властивості, новоутворення. У преамбулі галузевої Концепції розвитку неперервної педагогічної освіти зазначається: «Постійне вдосконалення системи підготовки ... науково-педагогічних і педагогічних працівників зумовлене зміною ролі 
людини у сучасному світі, баченням ідеалу освіченості людини та висуванням нових вимог до якості людського капіталу відповідно до культурно-духовних, суспільно-економічних $\mathrm{i}$ технологічних трансформацій, а також чисельних викликів глобального, європейського, національного, регіонального та місцевого рівнів» [7].

Науковцями з різних методологічних засад грунтовно й усебічно досліджуються різні аспекти професійної підготовки майбутнього вчителя (О. Абдулліна, О. Вознюк, О. Дубасенюк, О. Мороз, М. Нікандров, В. Сластьонін та інші), творчо використовуються класичні надбання в галузі підготовки майбутнього педагога. Проблема пошуку шляхів та засобів забезпечення якості професійної підготовки майбутніх педагогів-фахівців різних напрямів є стрижневою для сучасних дисертаційних досліджень Т. Дмитренко, О. Пєхоти, Г. Нагорної, Н. Гузій та багатьох інших науковців. Наголошується на необхідності підвищення результативності та забезпеченні гарантованої якості професійної підготовки майбутніх спеціалістів освітньої галузі за період навчання у вищій педагогічній школі. Водночас очевидним $\epsilon$ той факт, що в посттоталітарну добу професійно-педагогічна підготовка майбутнього вчителя потребує докорінних змін: ii цільове призначення, процесуальні та змістові аспекти зазнають суттєвих трансформацій. Відповідно, змінюються й функції педагогічних дисциплін, які $є$ стрижнем професійно-педагогічної підготовки. Mema цієї сmammi - шляхом порівняння та зіставлення висвітлити специфіку професійнопедагогічної підготовки майбутнього вчителя початкової школи й конкретизувати традиційні та новітні функції педагогічних дисциплін у вищому навчальному закладі.

У широкому значенні словосполучення «професійна підготовка» застосовується на позначення процесу оволодіння знаннями, уміннями та навичками, які дозволяють виконувати роботу в певній галузі діяльності [8, с. 482]. Від цілепокладання, добору змісту, визначення сталого та інваріантного, подальшого визначення методів, засобів, організаційних форм навчальної діяльності студентів залежить прикінцева ефективність начального процесу вищої школи i визначення тенденцій його вдосконалення в майбутньому. Загальні методологічні орієнтири абсорбують стратегічні програми, доктрини педагогічної освіти, на основі яких уточнюється специфіка професійної підготовки майбутніх педагогів, розробляються програми викладання педагогічних дисциплін, визначається зміст основних навчальних та варіативних курсів. Процеси оновлення професійної підготовки сучасного вчителя викликані низкою чинників, найважливіші 3поміж яких:

- соціально-економічні перетворення, які детермінують потребу кардинального оновлення системи вищої педагогічної освіти, методології та методів організації навальновиховного процесу у вищій педагогічній школі;

- неперервні зміни обсягу, складу навчальних дисциплін та їх складників, уведення нових навчальних предметів, або розділів дисциплін, які, у свою чергу, потребують постійного пошуку нових організаційних форм, методів навчання;

- надання викладачам самостійності у виборі нових програм, підручників, прийомів і способів педагогічної діяльності, проведення експериментів та досліджень (при постійному аналізі та оцінці компетентними експертами та органами управління освітою);

- існування вищих педагогічних навчальних закладів у ринкових умовах та створення реальної ситуації стимулювання конкурентоспроможності (Т. Дмитренко [4, с. 16]).

Наприкінці ХХ ст. у наукових публікаціях виокремлювалося до п’яти компонентів професійної підготовки вчителя, кожен 3 яких виконував свої завдання. У більшості досліджень такими компонентами визначалися: суспільно-політична підготовка, спеціальна 
підготовка, психолого-педагогічна підготовка, методична підготовка, загальнокультурна підготовка (за О. Абдулліною [1, с. 24-25]). На основі аналізу наукового доробку вітчизняних і зарубіжних науковців, можемо визначити, що професійно-педагогічна підготовка майбутнього вчителя - це інтегративний иілісний комплекс, якому притаманна внутрішня єдність компонентів, спрямованість на досягнення визначених стратегічних иілей педагогічної освіти, розкриття внутрішнього потенціалу особистості у майбутній педагогічній діяльності.

Чільну увагу варто приділити функціям професійно-педагогічної підготовки майбутнього вчителя,- питанню, яке має виняткове методологічне значення. Дослідники (О. Абдулліна, О. Мороз, Л. Петухова та інші) умовно розділяють ці функції на зовнішні, що відбивають можливості самої системи професійно-педагогічної підготовки, та внутрішні, які координують та інтегрують іiі зміст, відбивають характер позиціювання професійнопедагогічної підготовки щодо інших складників загальнопрофесійної підготовки, способи взаємодії цих складників, характер зв'язків тощо. У численних дослідженнях професійнопедагогічної підготовки науковці посилаються на висновки О. Абдулліної, яка надає аналіз функціям загальнопедагогічної підготовки. Спираючись на висновки вченої, надамо аналіз функціям професійно-педагогічної підготовки майбутнього вчителя в умовах сьогодення:

- освітня функиія є втіленням «спрямованості на озброєння студентів фундаментальним знанням основ педагогічної теорії, на формування у них системи загальнопедагогічних знань, умінь та навичок, необхідних для успішної педагогічної діяльності» [1, с. 35], відбиває як теоретичні, так і практичні аспекти професійнопедагогічної підготовки;

- професійно-розвивальна функиія відбиває тї вплив на розвиток професійної спрямованості мислення майбутніх педагогів, їх педагогічних здібностей, формування творчого підходу до педагогічної діяльності;

- виховальна функція зводиться до вироблення відповідального, творчого ставлення до вчительської праці (усвідомлення соціальної значущості педагогічної професії, інтерес до педагогічної діяльності), ставлення до себе як суб'єкта педагогічної діяльності, вимогливість, педагогічний такт [1, с. 36];

- координувальна та інтегрувльна функції відбивають об’єктивно існуючий природній взаємозв'язок педагогічних дисциплін 3 психологією, віковою фізіологією, частковими методиками, дисциплінами соціального, суспільно-політичного циклів [1, с. 36].

Професійно-педагогічна підготовка майбутнього вчителя початкової школи $\epsilon$ об'єктом досліджень таких сучасних науковців, як: О. Іонова, О. Комар, О. Кучерявий, С. Литвиненко, Н. Максименко, Д. Паращенко, Н. Сінопальнікова, Л. Хомич, Л. Хоружа та ін. Синтезуючи різні погляди дослідників, визначаємо професійно-педагогічну підготовку майбутнього вчителя початкової школи як частину загальнопрофесійної підготовки, $y$ процесі якої майбутній учитель початкових класів оволодіває комплексом наукових педагогічних знань, набуває професійні вміння та навички, щуо дозволяє йому в майбутньому успішно виконувати професійні функиії, розв'язувати повсякденні навчально-виховні проблеми у взаємодї̈ з учнями початкової иколи в урочний та позаурочний час, добирати в майбутньому оптимальні иляхи та засоби досягнення високої якості навчання дітей молодшого шкільного віку. Власне педагогічна підготовка складає основу професійної підготовки майбутнього педагога. Зіставляючи джерела набуття навчальної педагогічної інформації та мету педагогічної підготовки студентів, В. Загвязинський виокремлював чотири функиії вивчення педагогічних дисциплін у вищому педагогічному навчальному 
закладі: інформаційно-пізнавальна; виховально-ідеологічна; розвивальна; мотиваційностимулювальна [5]. В українському суспільстві й українській гуманітаристиці залишилося в минулому домінування в освітньому процесі заздалегідь установлених ідеологічних імперативів (друга функція). Що ж до функцій власне виховальних, то опосередковано зміст педагогічних дисциплін повинен сприяти вихованню найкращих рис людини-професіонала. Практика викладання психолого-педагогічних, гуманітарних дисциплін у західноєвропейських та північноамериканських вищих навчальних закладах свідчить про те, що на виховних аспектах наголос у процесі викладання не робиться: уважається, що до навчального закладу йде молода людина зі сформованими ідеалами, цінностями, установками. Призначення ж вищого навчального закладу- професійна підготовка. Ці трансформації, а також ті загальні орієнтири, які визначені євроінтеграційними та вітчизняними нормативними документами, дозволяють представити власне функиії змісту навчальних дисциллін у вищому педагогічному навчальному закладі у такому вигляді: світоглядно-конструктивна; науково-пізнавальна; функція стимулювання; розвивальноособистісна; прогностична. Деталізуємо й конкретизуємо кожну із виокремлених функцій.

Світоглядно-конструктивна функція педагогічних дисииллін. Сам термін «світогляд» набуває поширення завдяки працям I. Канта, зокрема, «Критиці здатності суджень», і означає цілісне осягнення людиною безкінечності світу, який осягається відчуттями. У словниках світогляд - це «форма суспільної самосвідомості людини, через яку вона сприймає, осмислює та оцінює навколишню дійсність як світ свого буття й діяльності, визначає і сприймає своє місце і призначення в ньому» [3, с. 299]. Уважається, що світогляд сприяє орієнтації людини у світі, відповідно, світоглядно-конструктивна функція педагогічних дисциплін визначає загальну орієнтацію суб'єктів навчального процесу в педагогічних явищах, фактах, педагогічній дійсності у цілому. Тож педагогічні дисципліни у вищому педагогічному навчальному закладі формують педагогічний світогляд майбутніх учителів початкових класів - систему поглядів, переконань, особистісних настанов, у яких відбивається ставлення до педагогічної дійсності і які є визначальними детермінантами професійної поведінки майбутнього вчителя. У філософській думці ХХ ст. виявляється тенденція до висвітлення та вивчення «персонального світогляду» (К. Ясперс [10]), підставою для цього є потреба людини в «духовній захищеності», яку (потребу) і покликано задовольнити світоглядне осмислення того, що відбувається, осмислення, яке може тлумачитись як підтримка і допомога в доланні життєвих труднощів, особливо в «межових ситуаціях». Відповідно, світоглядно-конструктивна функція педагогічних дисциплін утілюється у допомогу майбутньому вчителю осмислювати педагогічні реалії, на грунті цього осмислення конструювати власну професійно-педагогічну поведінку. Педагогічні дисципліни не можна схарактеризувати лише як прикладні, або як теоретичні. Дійсно, в педагогічних дисциплінах міститься переважно «знання про потрібне»,- «про те, як потрібно планувати, здійснювати, вдосконалювати педагогічну діяльність у відповідності до мети навчально-виховного процесу та умов, у яких він протікає» [9, с. 11]. На основі цих знань студенти моделюють власні дії, за допомогою педагогічної інформації безпосередньо впливають, перетворюють на краще навчально-виховний процес у вищому навчальному закладі у цілому (наприклад, активно послуговуються отриманими педагогічними знаннями під час вивчення часткових методик, у ході вивчення дисциплін соціально-гуманітарного циклу тощо).

Науково-пізнавальна функція педагогічних дисциплін у вищому педагогічному закладі освіти. «Лише повнота науки ліквідує однобічність мислення, до якої за необхідністю 
схильний будь-який спеціаліст, i забезпечує широту світогляду i терплячість...»,зауважував С. Гессен [2, с. 315]. Педагогічні дисципліни вищого педагогічного навчального закладу у комплексі повинні репрезентувати повноту науково-педагогічного знання. Це твердження аксіоматичне і не викликає заперечень. Однак, особистий багаторічний досвід викладання педагогічних дисциплін та безпосередні спостереження за процесом викладання цих дисциплін у вітчизняних закладах освіти дозволяють визначити науково-пізнавальну функцію як активовану серед інших функцій не повною мірою. Відповідь на питання: скільки і які саме новітні науково-педагогічні теорії, концепції, моделі (у тому числі численні дидактичні), представлені у дисертаційних працях, реально використовуються у процесі викладання педагогічних дисциплін і сприяють підвищенню якості навчального процесу після захисту авторами кандидатських чи докторських дисертацій, - відповідь ця $є$ очевидною для кожного студента й викладача-практика. I справа тут не лише у традиційному протистоянні інноваційного й традиційного. Значна кількість наукових досліджень, навіть за наявності безсумнівної корисності їх застосування залишаються незатребуваною широким викладацьким загалом через те, що автори цих новацій не несуть особистої відповідальності за використання результатів наукового пошуку та поширення цих результатів не виключно шляхом апробації під час участі у наукових форумах, а саме шляхом реального впровадження у навчальний процес, у тому числі- процес викладання педагогічних дисциплін. Відтак - маємо зниження науково-пізнавальної функції педагогічних дисциплін у загальному освітньому процесі. Існують, звичайно, й позитивні приклади: поширення наукового напряму порівняльної педагогіки призвело до появи у навчальних планах вищих педагогічних навчальних закладів нового курсу- «Порівняльної педагогіки», ідеї інтегрованого навчання спонукають викладачів до розробки комплексних навчальних програм і спецкурсів, таких, як «Педагогіка в особистостях» (А. Бойко та їі наукова школа) та інші. Та масова практика викладання педагогічних дисциплін у вищих педагогічних навчальних закладах не будується повною мірою на використанні новітніх наукових напрацювань. Між тим, потреба підвищення конкурентоспроможності вищих педагогічних навчальних закладів на ринку надання освітніх послуг вимагає негайного підсилення саме цієї функції педагогічних дисциплін. «Наукова нейтральність» йде в небуття, педагогіка як наука стає більш практикоорієнтованою, звідси змінюються (поки - дуже повільно) зміст та методика викладання педагогічних дисциплін. Викладач, розпочинаючи розроблення певного педагогічного курсу, уже на старті повинен чітко уявляти його цільове призначення у загальній структурі професійної підготовки майбутніх педагогів, які саме очікувані позитивні новоутворення будуть сформовані у студентів внаслідок застосування курсу, усі можливі шляхи забезпечення якості викладання.

Функція стимулювання. Комплекс педагогічних дисциплін покликаний закріпити у свідомості студентів позитивні мотиви обрання педагогічної професії, а зміст та хід вивчення педагогічних дисциплін - спонукати молоду людину до особистісного і професійного зростання, самовдосконалення, самоосвіти, викликати прагнення освоїти нові види діяльності, зрозуміти й освоїти нові професійні перспективи. На результатами численних опитувань студентської молоді (Є. Ільїн, Л. Подоляк, С. Розін, Д. Тхоржевський, М. Ховрич та інші) інтерес до обраної професії педагога, який спостерігається у першокурсників, неухильно зменшується рік від року навчання у вищому закладі освіти, темпи «падіння» трохи гальмуються на останніх курсах (своєрідною «зоною неповернення» уважається третій рік навчання студента у ВНЗ). Педагогічні дисципліни здатні докорінно змінити цю ситуацію: за рахунок усвідомлення студентами ролі і значення освіти у житті людини та 
суспільства, завдяки застосуванню цікавих для студента форм організації навчального процесу, залучення навчальної інформації, яка сприяє становленню майбутнього вчителя як педагога нової формації, здатного упевнено й оперативно взаємодія ти з іншими в реальному та мереживному середовищі тощо. Функція стимулювання, яку виконують педагогічні дисципліни, у сучасних умовах підсилюється за рахунок застосування у навчальному процесі сучасних мультимедійних засобів навчання, доборі викладачами діалогових форм навчальної взаємодії, розширення сфери консультативних послуг. Застосування для цієї функції означення «стимулювальна» вважаємо більш виправданим і точним 3 наукової точки зору (ніж «мотиваційно-стимулювальна» [5]), адже «мотиви завжди внутрішні, - за твердженням Є. Ільїна, - на відміну від стимулів, що викликають процес мотивації» [6, с. 114].

Розвивально-особистісна функція. Педагогічні дисципліни у вищому педагогічному начальному закладі сприяють загальному розвитку студентів i як особистостей, i як педагогів-професіоналів, оскільки їх викладання вимагає не тільки і не скільки викладання як такого, скільки «сповідальності» (визначення С. Гессена [2, с. 318]) викладачем-науковцем своїх поглядів, активації власного педагогічного досвіду (нерідко - власного позитивного й негативного родинного досвіду), унесення до навчального процесу елементів особистісного забарвлення навчальної інформації, особистої причетності. I саме у такий спосіб здійснюється безпосередній уплив на процес особистісного розкриття студентів у навчальній діяльності, становлення індивідуальної системи професійно-педагогічних цінностей, яка у подальшій професійній діяльності буде відігравати вирішальну роль. Унаслідок таких дій студенти усвідомлюють (або переосмислюють) свою роль у накопиченні педагогічних цінностей у галузі розв’язання теоретичних і прикладних завдань навчання.

Прогностична функція педагогічних дисциплін (Б. Гершунський) є безпосереднім відбиттям прогностичної функції педагогічної науки, іiї «зверненості у майбутнє». Безперечно, як і кожна наука, педагогіка пояснює й описує ту дійсність, яку вивчає. Знання загальних закономірностей навчального процесу, пошук та констатація часткових закономірностей дозволять сучасним студентам у майбутньому здійснювати короткочасне й довготривале прогнозування, наприклад, прогнозування інтенсивності та прикінцевої результативності засвоєння учнями навчальної інформації з певної навчальної дисципліни за наявності певних умов тощо. Прогностична функція педагогічних дисциплін активізується саме в середовищі жорсткої конкуренції, адже швидкозмінна кон'юнктура на ринку освітніх послуг вимагає саме від педагогічних дисциплін надання сучасним студентам відповідного дидактико-методичного інструментарію, вироблення у процесі вивчення циклу педагогічних дисциплін аналітико-прогностичних здібностей, розвитку нестандартного мислення, особистої ініціативи, сформувати установки на саморозвиток конкурентоздатності в освітній cфepi.

Отже, на основі порівняння та зіставлення функцій професійно-педагогічної підготовки та функцій педагогічних дисциплін у вищому педагогічному навчальному закладі можемо зробити висновок про те, що в новітніх умовах соціально-економічні й політичні трансформації українського суспільства спонукають до видозмін сталих функцій, додають нового забарвлення. Водночас ми не можемо не зважати на ті проблеми, які є спільними для фахової підготовки вчителів початкової школи та визначальними для нових наукових розвідок. Це проблеми, пов'язані, перш за все, з недостатньою розробленістю теоретичних засад професійно-педагогічної підготовки майбутніх учителів початкових класів в умовах запровадження дворівневого циклу підготовки, проблеми відбору та структурування змісту педагогічної підготовки, недосконалість механізмів оцінювання результатів навчальної 
роботи майбутніх учителів початкової школи за новими оцінними стандартами і шкалами, зростання масовості вищої педагогічної освіти за рахунок певного зниження якості фахової підготовки. Розв'язання цих проблем - невідкладне завдання для майбутніх досліджень.

\section{Література}

1. Абдуллина О. А. Общепедагогическая подготовка учителя в системе высшего педагогического образования / О. А. Абдуллина. - Москва : Просвещение, 1990. - 141 с. 2. Гессен С. И. Основы педагогики. Введение в прикладную философию / Сергей Иосифович Гессен. - Москва : Школа-Пресс, 1995. - 448 с. 3. Гончаренко С. У. Український педагогічний словник/ Семен Устимович Гончаренко. - Київ : Либідь, 1997. - 376 с. 4. Дмитренко Т. А. Профессионально-ориентированные технологии обучения в системе высшего педагогического образования (на материале преподавания иностранных языков) : дисс. ... д-ра пед. наук : 13.00.08; 13.00 .02 / Дмитренко Татьяна Алексеевна. - Москва, 2004. 445 с. 5. Загвязинский В. И. Учитель как исследователь / Владимир Ильич Загвязинский. Москва : Педагогика, 1980. - 192 с. б. Ильин Е. П. Мотивация и мотивы / Евгений Павлович Ильин. - Санкт-Петербург : Питер, 2011. - 512 с. 7. Концептуальні засади розвитку педагогічної освіти України та ії інтеграції в європейський освітній простір (Затверджено наказом МОН України від 23.01.2004p. № 48) [Електронний ресурс]. - Режим доступу: http : // www.mon.gov.ua/ main.php?query=education 8. Педагогика: Большая современная энциклопедия / сост. Е. С. Рапацевич. - Минск : Современное слово, 2005. - 720 с. 9. Харламов И. Ф. Педагогика / Иван Федорович Харламов / под ред. П. И. Пидкасистого. Москва : Педагогическое общество России, 1998. - 638 с. 10. Ясперс К. Духовная ситуация времени [Электронный ресурс]/ Карл Ясперс.- Режим доступу: http://fast.filedownloads.org/?metod=FAST\&cost=FREE\& file_id $=2267675$

\section{ШЛЯХИ ОНОВЛЕННЯ ОБЧИСЛЮВАЛЬНОЇ ПРАКТИКИ У ПРОЦЕСІ ПІДГОТОВКИ БАКАЛАВРА МАТЕМАТИКИ}

Самойленко О. М. Шляхи оновлення обчислювальної практики у процесі підготовки бакалавра математики.

Статтю присвячено питанням професійної підготовки бакалаврів математики у процесі проведення навчальної обчислювальної практики. У статті описано особливості обчислювальної практики бакалаврів математичних дисциплін. Здійснено аналіз тематики проектів обчислювальної практики. Проаналізовано загальні закономірності структури та змісту програмних продуктів підтримки професійної діяльності учителів математики, які розробляють студенти під час обчислювальної практики.

Ключові слова: обчислювальна практика, математика, професійна підготовка, профільне навчання, навчальна практика.

Самойленко А. М. Пути усовершенствования вычислительной практики в процессе подготовки бакалавра математики.

Статья посвящена вопросам профессиональной подготовки бакалавров математики в процессе проведения учебной вычислительной практики. В статье описаны особенности вычислительной практики бакалавров математических дисциплин. Дан анализ тематики проектов вычислительной практики. Проанализированы общие закономерности структуры и 